\title{
Demonstration of three anomalous plasma proteins induced by a vitamin $\mathrm{K}$ antagonist
}

Citation for published version (APA):

Reekers, P. P. M., Lindhout, M. J., Kop-Klaassen, B. H. M., \& Hemker, H. C. (1973). Demonstration of three anomalous plasma proteins induced by a vitamin $\mathrm{K}$ antagonist. Biochimica et Biophysica Acta (BBA) - Protein Structure, 317(2), 559-562. https://doi.org/10.1016/0005-2795(73)90252-3

Document status and date:

Published: 01/01/1973

DOI:

10.1016/0005-2795(73)90252-3

Document Version:

Other version

\section{Please check the document version of this publication:}

- A submitted manuscript is the version of the article upon submission and before peer-review. There can be important differences between the submitted version and the official published version of record.

People interested in the research are advised to contact the author for the final version of the publication, or visit the DOI to the publisher's website.

- The final author version and the galley proof are versions of the publication after peer review.

- The final published version features the final layout of the paper including the volume, issue and page numbers.

Link to publication

\footnotetext{
General rights rights.

- You may freely distribute the URL identifying the publication in the public portal. please follow below link for the End User Agreement:

www.umlib.nl/taverne-license

Take down policy

If you believe that this document breaches copyright please contact us at:

repository@maastrichtuniversity.nl

providing details and we will investigate your claim.
}

Copyright and moral rights for the publications made accessible in the public portal are retained by the authors and/or other copyright owners and it is a condition of accessing publications that users recognise and abide by the legal requirements associated with these

- Users may download and print one copy of any publication from the public portal for the purpose of private study or research.

- You may not further distribute the material or use it for any profit-making activity or commercial gain

If the publication is distributed under the terms of Article $25 \mathrm{fa}$ of the Dutch Copyright Act, indicated by the "Taverne" license above, 
Reprinted from

Biochimica et Biophysica Acta, 317 (1973) 559-562

(c) Elsevier Scientific Publishing Company, Amsterdam - Printed in The Netherlands

\section{BBA Report}

BBA 31162

Demonstration of three anomalous plasma proteins induced by a vitamin $\mathrm{K}$ antagonist 


\section{BBA Report}

BBA 31162

\section{Demonstration of three anomalous plasma proteins induced by a vitamin $\mathrm{K}$ antagonist}

\section{P.P.M. REEKERS, M.J. LINDHOUT, B.H.M. KOP-KLAASSEN and H.C. HEMKER}

Laboratory for Cardiovascular and Blood Coagulation Biochemistry, Leiden University Medical Centre, Leiden (The Netherlands)

(Received June 15th, 1973)

\section{SUMMARY}

With the aid of precipitating antibodies against the bovine coagulation factors II, IX, and X three immunologically non-identical proteins can be demonstrated that are induced by the administration of a vitamin $\mathrm{K}$ antagonist (phenprocoumon). Each of these proteins is immunologically identical to one of three coagulation factors mentioned.

The proteins differ from normal coagulation factors (a) by a lack of biological activity; (b) by a faster anodic migration rate in the presence of $\mathrm{Ca}^{2+}$. factor.

The proteins appear in the plasma concomitantly with the decrease of the normal

In 1963 we reported experiments that led us to conclude that under conditions of vitamin $\mathrm{K}$ deficiency (either absolute or induced by vitamin $\mathrm{K}$ antagonists), plasma contains an anomalous prothrombin-like protein ${ }^{1}$. At that time we postulated that this protein is a precursor of prothrombin that reaches the circulation because a postribosomal vitamin $\mathrm{K}$ dependent step in the synthesis of prothrombin is blocked.

Later, an abnormal prothrombin-like protein was demonstrated in the vitamin $\mathrm{K}$ deficient human ${ }^{2,3}$ as well as in the deficient $\operatorname{cow}^{4}$. This protein cannot be distinguished from normal prothrombin in immunodiffusion tests, but in the presence of $\mathrm{Ca}^{2+}$ it shows a higher electrophoretic mobility than normal prothrombin.

It has been shown that after the start of oral anticoagulant treatment the abnormal protein gradually increases concomitantly with the decrease of normal prothrombin ${ }^{5}$.

Research at the cellular and subcellular levels (e.g. Suttie, ref. 6) made it probable that vitamin $\mathrm{K}$ does act at a postribosomal step in prothrombin synthesis and that a protein

Abbreviation: PIVKA, protein induced by vitamin $\mathrm{K}$ absence. 
precursor to prothrombin does exist. Since there are four vitamin K-dependent coagulation factors (II, VII, IX, and X) the existence of four different precursors can be postulated. An increased cellular concentration of these precursors could conceivably cause the occurrence of proteins induced by vitamin $\mathrm{K}$ absence (PIVKAs) in the blood. Four precursors suggest four PIVKAs, which can be designated PIVKA-II, PIVKA-VII, PIVKA-IX, and PIVKA-X.

Indirect evidence based on antibody neutralization and coagulation kinetics suggests the existence in man of PIVKA-IX and PIVKA-X in addition to PIVKA-II (refs 7-9).

The present report concerns the demonstration of the occurrence of PIVKA-IX and PIVKA-X as well as PIVKA-II in the plasma of the anticoagulated cow.

We purified the bovine coagulation factors II, VII, IX, and $\mathrm{X}$ by $\mathrm{Al}(\mathrm{OH})_{3}$ adsorption, DEAE-cellulose chromatography, and preparative acrylamide gel electrophoresis (for a full account of the methods see ref. 10), and immunized rabbits with these preparations. We obtained highly specific antibodies against factors II, IX, and X, but failed to obtain antibodies against factor VII.

Administration of phenprocoumon in a dose of $250 \mathrm{mg}$ daily to a cow weighing $500 \mathrm{~kg}$ caused the expected decrease in the activity of factors II, VII, IX, and X. $24 \mathrm{~h}$ after the first dose, the plasma contained the following concentrations of coagulation factors: prothrombin, 75\%; factor VII, 24\%; factor IX, 50\%; and factor X, 38\%. After $100 \mathrm{~h}$, the plasma contained $23 \%$ of the original amount of prothrombin and less than $5 \%$ of that of each of the other factors. All coagulation factor determinations were carried out in onestage assays as described in refs 11 and 12 .

The plasmas were submitted to electrophoresis in $1 \%$ agarose in the presence of calcium lactate $(2 \mathrm{mM}$ ) in $0.075 \mathrm{M}$ barbital buffer at $\mathrm{pH} 8.6$ as described by Ganrot and Nilehn ${ }^{3}$. After the agarose slabs had been transferred to a square glass plate $(20 \mathrm{~mm} x$ $10 \mathrm{~mm} \times 1 \mathrm{~mm}$ ) and incorporated into an agar gel containing the specific antibody, crossed immunoelectrophoresis was carried out by applying $50 \mathrm{~V}$ for $4 \mathrm{~h}$ in a direction

perpendicular to the first one. With normal plasma and each of the antibodies, a single peak was obtained. Simultaneous incorporation of the three antibodies into one gel gave three separate, non-identical peaks (Fig. 1, top), thus indicating the existence of three separate antibody-antigen interactions. When plasma was adsorbed with $\mathrm{Al}(\mathrm{OH})_{3}-\operatorname{gel}(1.0 \% \mathrm{w} / \mathrm{v})$ to eliminate factors II, VII, IX, and X, no precipitation pattern was obtained. With plasma withdrawn $24 \mathrm{~h}$ after the first administration of phenprocoumon, a "camelback" pattern was obtained. Each of the antibodies gave two partly separated peaks, one corresponding to the normal factor, and the other to the faster-moving abnormal species. The continuity of the precipitation lines indicates immunological identity. Thus, the plasma contains one abnormal molecular species corresponding to each of the three normal factors. This indicates that PIVKA-IX and PIVKA-X exist as well as PIVKA-II, which can be elegantly demonstrated by incorporating all three antibodies into the agarose gel used for the second electrophoresis. When this is done, three groups of two peaks are observed. Within each group there is complete identity; between the groups there is no identity (Fig. 1, middle). When prolonged anticoagulation leads to almost complete absence of factor IX and X activity $(<5 \%)$, the crossed electrophoresis pattern (Fig. 1, bottom) is consistent with 


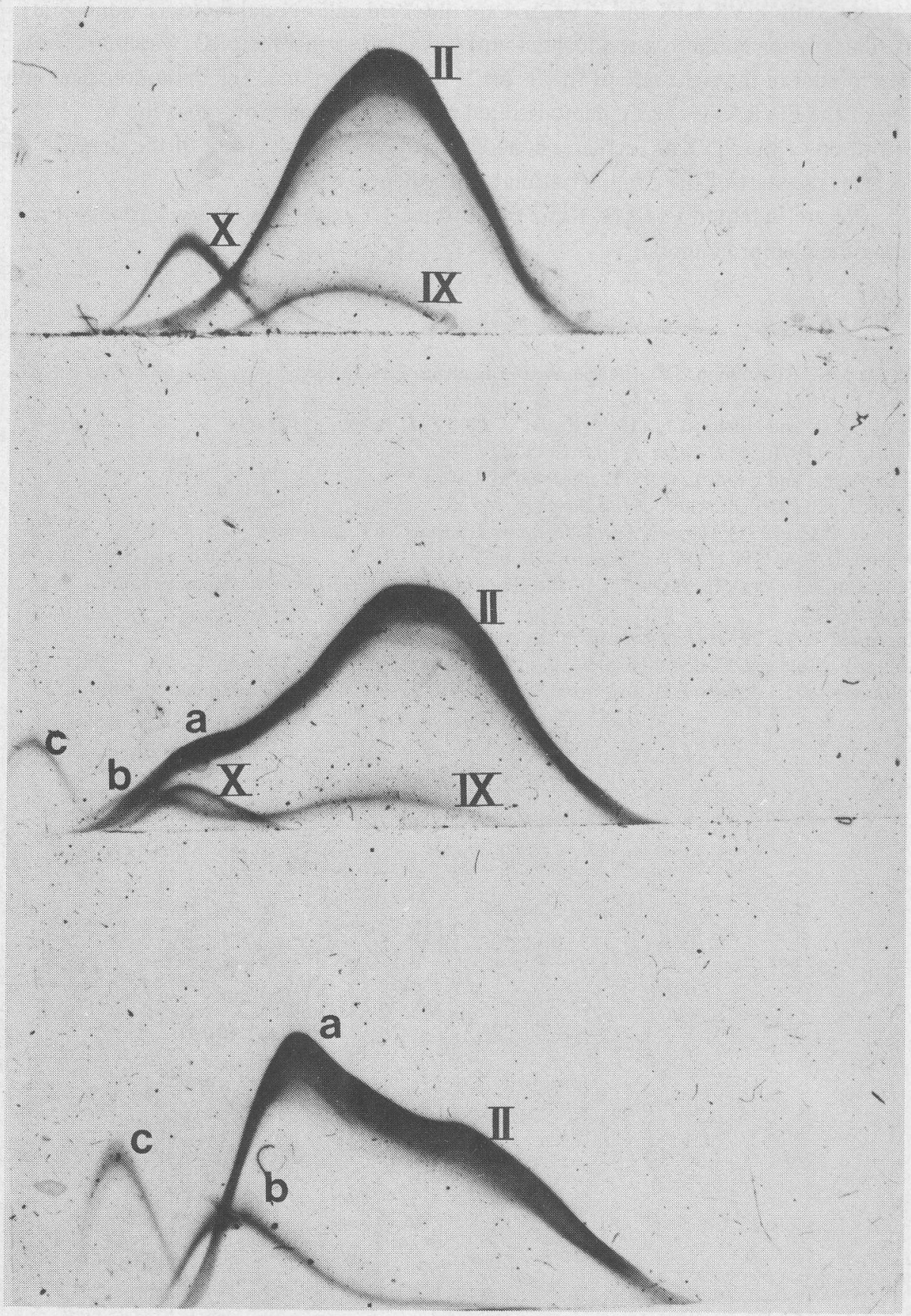

Fig. 1. Two-dimensional crossed electrophoresis of bovine plasmas against a mixture of anti-factor II, anti-factor IX, and anti-factor X present in the second (vertical) dimension. Top, normal plasma; Middle, plasma after $24 \mathrm{~h}$ of anticoagulation; Bottom: plasma after $100 \mathrm{~h}$ of anticoagulation. The figures II, IX, and $\mathrm{X}$ indicate the peaks obtained with the normal factors, the letters $\mathrm{a}, \mathrm{b}$, and $\mathrm{c}$ the corresponding fastmoving proteins. 
expectation: only PIVKA-IX and PIVKA-X are observed and normal factors IX and X are absent. This plasma contains a residual amount (23\%) of normal factor II, which accounts for the shoulder in the right side of the factor II precipitation line. The immunological nonidentity of the PIVKAs is clearly demonstrated by Fig. 1, which shows that the concentration of the PIVKAs increases concomitantly with the decrease of the normal factors after the start of the administration of the phenprocoumon.

We are indebted to Dr M. Kunz of Hoffman-La Roche, Basel, Switzerland, for providing the phenprocoumon.

\section{REFERENCES}

1 Hemker, H.C., Veltkamp, J.J., Hensen, A. and Loeliger, E.A. (1963) Nature 200, 589-590

2 Josso, F. (1971) Blood 38, 9-16

3 Ganrot, P.O. and Nilehn, J.E. (1968) Scand. J. Clin. Lab. Invest. 22, 23-28

4 Stenflo, J. (1970) Acta Chem. Scand. 24, 3762-3763

5 Brozovic, M. and Gurd, L. (1971) Lancet II, 427-428

6 Sutie, J.W. (1970) Arch. Biochem. Biophys. 141, 571-578

7 Hemker, H.C. (1971) Thromb. Diath. Haemorrh. Suppl. XLV, 119-124

8 Denson, K.W.E. (1971) Br. J. Haematol. 20, 643-648

9 Veltkamp, J.J., Muis, H., Muller, A.D. and Hemker, H.C. (1971) Thromb. Diath. Haemorrh. $25,312-315$

10 Reekers, P.P.M. (1973) Haemostasis, in the press

11 Koller, F., Loeliger, E.A. and Duckert, F. (1951) Acta Haematol. 6, 1-18

12 Veltkamp, J.J., Loeliger, E.A. and Drion, E.F. (1968) Thromb. Diath. Haemorrh. 19, 403-422 